\title{
The Instrument Development to Evaluate Local Curriculum in Indonesia
}

\author{
Dedek Andrian \\ Corresponding autor, Yogyakarta State University, Indonesia, \\ dedek.andri321@gmail.com
}

Badrun Kartowagiran

Yogyakarta State University, Indonesia, badrunkw@yahoo.com

Samsul Hadi

Yogyakarta State University, Indonesia, samsul.hd@gmail.com

The purpose of this research is to develop an instrument to evaluate local curriculum developed by the local government. Local curriculum is to preserve the uniqueness or culture of the Region. With a well-run educational system, students as young people can develop local or regional uniqueness. Type of this research is a research and development consisting of four phases: 1) initial investigation phase, 2) design phase and 3) expert validation phase, and 4) trial phase. From the initial investigation obtained 3 components of the evaluation that is; 1) resources component; 2) process component; 3 ) output component. The design phase is done by studying the theory and developing the instrument in the form of the questionnaire as many as 60 items. Expert validation phase is done by 2 evaluation experts, 1 measurement expert, and 8 practitioners. The results were analyzed using Aiken's validity. The trial phase is done 2 times in small scale and large-scale trials. The small-scale trial was analyzed by confirmatory factor analysis and Cronbach's Alpha reliability. The large-scale trial was analyzed by confirmatory factor analysis and construct reliability. From the results of validity and reliability obtained 50 items of the instrument is valid and feasible to be used to evaluate local curriculum developed by local government. The instrument is effective in evaluating the local curriculum

Keywords: development, instrument, evaluation, local curriculum, curriculum development

\section{INTRODUCTION}

Indonesia is a country rich in diversity. The diversity of the Indonesian state can be seen from the many tribes and cultures that color in every region. This diversity shows that Indonesia is a country that has unique features that are not owned by other countries

Citation: Andrian, D., Kartowagiran, B., \& Hadi, S. (2018). The Instrument Development to Evaluate Local Curriculum in Indonesia. International Journal of Instruction, 11(4), 921-934. https://doi.org/10.12973/iji.2018.11458a 
because each region has its own distinct cultural uniqueness. The uniqueness of the culture owned by every region in the State of Indonesia needs to be maintained. Elements of government and society need to contribute in maintaining cultural heritage so as not to disappear with the rapidly growing information technology as they are a product of culture(Gavareshki, Haddadian, \& HassanzadehKalleh, 2012). Characteristics and cultures are heritages that must be preserved from generation to generation(Hall, 2005). Elements of government and society must work together in maintaining the characteristics and culture owned by every region in Indonesia. Local governments through their budgets can develop local cultures into interesting objects(Środa-Murawska, Biegańska, \& Dąbrowski, 2017). The result of the development of local culture can be a source of economic growth of a region (Tubadji, 2012).

Learners should preserve and develop the characteristics and culture because they are members of the community who must understand the cultural values of a region(Emin, 2013). Social learning activities can shape the values and norms of learners significantly (Shih, Velan, \& Shulruf, 2017). Learning activities can be an effective business for learners to be more in love with the characteristics and culture of the region (Prastiwi, 2013).Introducing culture through education can transform the value of kindness to students (Strouse \& Nickerson, 2016). With adapting to the surrounding culture, students can design knowledge (Temli Durmuş, 2016).

A local curriculum is a form of decentralized education regulated in the regulation of the Minister of Education and Culture No. 22 of 2006 on content standards. The local curriculum is an integral part of the national curriculum for which learning activities exist in elementary and secondary education (Depdiknas, 2006). The local curriculum is an integral part of the national curriculum which is intensively carried out from the 1994 curriculum, the 2004 curriculum, the 2006 curriculum and the 2013 curriculum. In Indonesia, the local curriculum becomes an important part of the national curriculum and is given to regions to develop local governments. The authority given by the central government to regional governments can be an effective means of developing a regional curriculum.

Governmental decentralization gives local governments the power and authority to manage education (Chan \& Wang, 2009). Local governments can collaborate with schools to incorporate regional characteristics and cultures into learning activities because schools are empowered to manage the curriculum (Law, 2009). Distinction in managing education provided by the central government can make education more effective (Papadopoulou \& Yirci, 2013). Decentralization of education makes the school more familiar and understands its duty in developing its own characteristics or culture (Chapman, Barcikowski, Sowah, Gyamera, \& Woode, 2002). Schools that understand the region can develop the characteristics and develop the quality of education (Qi, 2011).

The local curriculum is developed by local governments as a means of developing the regional characteristics packed in learning activities. Local governments can add lessons that contain regional characteristics. Local governments coordinate with schools to 
realize the curriculum developed by the regions. Schools should prepare facilities and infrastructure that can support the success of local curriculum developed by the local government. The introduction of culture to the younger generation can be effectively implemented through the local curriculum. The local curriculum can provide insight to learners about the importance of maintaining and preserving the culture and regional characteristics.

The local curriculum makes schools more confident and improves school satisfaction in work (Doherty \& Shield, 2012). With learning activities, skill and teacher capacity are better so that they are able to develop innovation in the local curriculum (Sahasewiyon, 2004). The local curriculum provides autonomy to schools especially teachers in improving professional competence as teachers. The local curriculum offers an insight into schools to develop their own characteristics and culture through the education system (Mølstad, 2015). Schools that implement local curriculum can practice cultural characteristics in teaching and learning activities (Johansson, 2009). The local curriculum developed by the government should be evaluated so that the shortcomings or weaknesses of the local curriculum can be detected. Problems in learning activities can be detected by evaluating the curriculum (Haghparast, Sedghizadeh, Shuler, Ferati, \& Christersson, 2007). Curriculum evaluation is a potential activity in building communication between students, teachers, and staff so that learning outcomes can be expected to be obtained (Harris, Driscoll, Lewis, Matthews,\& Russell., 2010).

Based on the explanation about the importance of maintaining the regional characteristics through the curriculum, the evaluation of the curriculum is a study which must be done by the school. To evaluate a curriculum requires an accurate instrument that meets the valid and reliable criteria. Instruments to collect must be valid and reliable based on content and constructs in order to obtain accurate information(Ungar \& Santos, 2003). The concept of validity and reliability is very important in the development of the instrument. Instruments that meet the valid and reliable criteria can illustrate the results of actual research. An Instrument that meets the valid and reliable criteria can result in quality measurement (Bayraktar, Tatoglu, \& Zaim, 2008).

\section{Context and Literature Review}

The curriculum is the sum of the activities and learning experiences that students perceive with school guidance (Festus \& Kurumeh, 2015; Fink, C.R., \& Crunkilton, 1999; Howell, K.W.,\& Nolet, 2000). The curriculum is a total means of experience experienced by students through school guidance (Syomwene, Kitainge, \& Mwaka, 2013). A curriculum is a basic element in the education system that includes the standards expected to be achieved (Akınoğlu, 2017). Based on these statements it can be concluded that the curriculum is the total means of all experience or educational program planned for students with school-made guidelines.

The curriculum provides guidance and a foundation for schools in developing learning and assessment. Efforts to improve the curriculum in order to achieve successful learning becomes something that absolutely must be done (Briggs, 2007). The curriculum provides opportunities for students to learn well and practically (Squires, 
2013). The success of the learning process will be realized if curriculum practices work well and are based on assessment (Mcgaw, 2013). The success of the learning process can also occur when school elements innovate in the curriculum (Brundrett \& Duncan, 2011). Teachers must be able to adapt to the developed curriculum and are not afraid of the demands to be achieved (Umami, 2018). The curriculum is the foundation of the learning activities. Curriculum evaluation is a potential activity in building communication between students, teachers, and staff so that learning outcomes can be expected to be obtained. Based on the above explanation it can be concluded that the evaluation of the curriculum is an absolute thing that must be done by the school.

Curriculum evaluation is an important aspect of curriculum development. The curriculum evaluation is vital and should be done by the school so that all weaknesses of the curriculum-building aspect can be described(Salim Saif Al-Jardani, 2012). A curriculum evaluation can show how far the educational objectives have been successful(Gilbert, 2004). Educational needs can be analyzed and identified through curriculum evaluation activities(Lie, John, Crandall, Degannes, Henderson, Kodjo, \&Degannes, 2009). With curriculum evaluation, student skills in person, student achievement in general and students' interpersonal relationships can be improved(Curtis \& Norgate, 2007). Curriculum evaluation can provide crucial things that must be improved in curriculum development. Methods of learning, student satisfaction in learning, student learning outcomes need to be evaluated(Zedda, Bernardelli, \& Maran, 2017). Evaluations can help align educational goals in general and school missions(Heimlich, 2010). Evaluation activities can be the standard of teacher success in transferring knowledge to learners (Jacob \& Lefgren, 2008).

\section{METHOD}

Research on instrument development to evaluate local curriculum developed by the local government using research and development. The purpose of this research is to produce an instrument of a questionnaire to evaluate local curriculum implementation developed by the local government. The research and development model used is the Borg \& Gal (1983) model consisting of 10 simplified steps into four steps: (1) initial investigation, (2) design stage, (3) expert validation and; (4) trials, evaluations, and revisions. Initial investigations used qualitative research with a phenomenological approach. Data were collected using focus group discussion (FGD) techniques with 14 Participants consisting of 6 vice principals and 8 local curriculum teachers. The purpose of the FGD is to obtain constructs that can be used to evaluate the local curriculum. From the FGD results it was found that there were several factors that became the basis for evaluating the local curriculum, namely; 1) government support, school support, student motivation, equipment, materials, and funds are summarized into resource factors; 2) teacher preparation, implementation, formative assessment and summative assessment summarized into process factors; 3) students' knowledge, student attitudes, student skills and entrepreneurial desires are summarized into output factors. The instrument design phase was conducted by developing a questionnaire. Validation Phase conducted by 2 evaluation experts or 1 measurement expert and 8 practitioners. The validation phase aims to see the validity of the contents of the developed questionnaire. 
Content validity affects the accuracy of data to be obtained in the field. Trials were conducted 2 times, in small and large-scale trial. The small-scale trial aims to see the validity of content empirically, namely by distributing items of the questionnaire developed to respondents. The large-scale trial aims to see the validity and reliability of instrument constructs.

\section{Sample \&Sampling Technique}

The sample used in this study is senior high school students who implement the local curriculum. The sampling technique used is purposive sampling. The reason for choosing purposive sampling technique is because it can select the samples correctly according to the criteria and the number of samples to be used for the research(Eğmir, Erdem, \& Koçyiğit, 2017).

\section{Instrument}

The instrument used in this study is a questionnaire. The questionnaires that have been developed are then validated by experts. The questionnaire developed amounted to 60 items consisting of 4 items of government support (GS1, GS2, GS3, GS4), 5 items of school support (SS1, SS2, SS3, SS4, SS5), 4 items of student motivation (SM1, SM2, SM3, SM4), 5 items of equipment (Eq1, Eq2, Eq3, Eq4, Eq5), 5 items of material (Ma1, Ma2, Ma3, Ma4, Ma5), 5 items of fund (Fu1, Fu2, Fu3, Fu4, Fu5), 4 items of teacher preparation (TP1, TP2, TP3, TP4), 5 items of implementation (Im1, Im2, Im3, Im4, Im5), 3 items of formative assessment (FA1, FA2, FA3), 4 items of sumative assessment (SA1, SA2, SA3, SA4), 4 items of knowledge (Kn1, Kn2, Kn3, Kn4), 4 items of attitudes (At1, At2, At3, At4), 4 items of skill (Sk1, Sk2, Sk3, Sk4) and 4 items of entrepreneurship desire (ED1, ED2, ED3, ED4).

\section{Data analysis technique}

There are four phases of data analysis performed in this study.Data analysis of initial investigation phase, data analysis of expert validation phase, data analysis of small-scale trial data and data analysis of the large-scaletrial. Data analysis at the initial investigative phase used the method proposed by Creswell (2014): preparing and defining data, reading the data as a whole, coding data to define themes and create descriptions, link themes, and interpret themes. Data analysis of validation phase of expert use Aiken's V formula to see instrument items based on expert judgment(Aiken, 1980). Data analysis at small-scale trialphase using confirmatory factor analysis to see the validity of content empirically. The data analysis of the large-scale trial phase also uses confirmatory factor analysis to see the validity of the constructs. The effectiveness of the model was analyzed using descriptive statistics by creating categories, namely 3.26 to 4.00 with very good or very effective categories; 2.51 to 3.25 with good or effective category: 1.76 to 2.50 with good enough or effective enough category; and 1 to 1.75 with not good or ineffective categories (Sultan, Rofiuddin, Nurhadi, \& Priyatni, 2017).The effectiveness is assessed partially using an expert or practitioner who has used the instrument, as no previous instrument has been developed to evaluate the curriculum. This method can be used if no model, instrument or product has been developed previously to assess a program(Cashmore, Bond, \& Sadler, 2009; MorrisonSaunders \& Arts, 2004). 


\section{FINDINGS}

\section{Content validity with Aiken's V formula}

The developed instrument was assessed by two evaluation experts, one measurement expert and eight practitioners consisting of principals and local subject teachers. Experts and practitioners provide criteria, are highly relevant, relevant, irrelevant, and highly irrelevant. Expert assessment results are analyzed by Aiken's validity with categories ie; 0.0 to 0.4 low or cannot be used, 0.4 to 0.8 medium category or can be used with improvement, and 0.8 to 1.00 including the high category or can be used for research. The results of the analysis can be seen in Table 1 .

Table 1

The Result of Aiken's V

\begin{tabular}{|c|c|c|c|c|c|c|c|c|c|c|c|}
\hline \multicolumn{4}{|c|}{ Resource } & \multicolumn{4}{|c|}{ Process } & \multicolumn{4}{|c|}{ Output } \\
\hline Item & $\sum$ & $\mathrm{V}$ & Criteria & Item & $\sum$ & $\mathrm{V}$ & Criteria & Item & $\sum$ & $\mathrm{V}$ & Criteria \\
\hline GS1 & 24 & 0.889 & High & TP1 & 19 & 0.70 & Moderate & Kn1 & 20 & 0.74 & Moderate \\
\hline GS2 & 22 & 0.815 & High & TP2 & 24 & 0.89 & High & $\mathrm{Kn} 2$ & 23 & 0.85 & High \\
\hline GS3 & 24 & 0.889 & High & TP3 & 23 & 0.85 & High & Kn3 & 23 & 0.85 & High \\
\hline GS4 & 24 & 0.889 & High & TP4 & 22 & 0.81 & High & $\mathrm{Kn} 4$ & 25 & 0.93 & High \\
\hline SS1 & 9 & 0.333 & Low & Im1 & 10 & 0.37 & Low & At1 & 26 & 0.96 & High \\
\hline SS2 & 25 & 0.926 & High & $\operatorname{Im} 2$ & 22 & 0.81 & High & At2 & 7 & 0.26 & Low \\
\hline SS3 & 26 & 0.963 & High & $\operatorname{Im} 3$ & 23 & 0.85 & High & At3 & 21 & 0.78 & Moderate \\
\hline SS4 & 23 & 0.852 & High & $\operatorname{Im} 4$ & 21 & 0.78 & Moderate & At4 & 22 & 0.81 & High \\
\hline SS5 & 22 & 0.82 & High & $\operatorname{Im} 5$ & 18 & 0.67 & Moderate & Sk1 & 22 & 0.81 & High \\
\hline SM1 & 21 & 0.78 & Moderate & FA1 & 6 & 0.89 & High & $\mathrm{Sk} 2$ & 21 & 0.78 & Moderate \\
\hline SM2 & 21 & 0.78 & Moderate & FA2 & 25 & 0.93 & High & Sk3 & 25 & 0.93 & High \\
\hline SM3 & 9 & 0.33 & Low & FA3 & 24 & 0.89 & High & Sk4 & 25 & 0.93 & High \\
\hline SM4 & 21 & 0.78 & Moderate & FA4 & 23 & 0.85 & High & ED1 & 22 & 0.81 & High \\
\hline Eq1 & 24 & 0.89 & High & SA1 & 25 & 0.93 & High & ED2 & 10 & 0.37 & Low \\
\hline Eq2 & 23 & 0.85 & High & SA2 & 10 & 0.67 & Moderate & ED3 & 21 & 0.78 & Moderate \\
\hline Eq3 & 21 & 0.78 & Moderate & SA3 & 23 & 0.85 & High & ED4 & 24 & 0.89 & High \\
\hline $\mathrm{Eq} 4$ & 22 & 0.82 & High & & & & & & & & \\
\hline Eq5 & 21 & 0.78 & Moderate & & & & & & & & \\
\hline Ma1 & 24 & 0.89 & High & & & & & & & & \\
\hline $\mathrm{Ma} 2$ & 23 & 0.85 & High & & & & & & & & \\
\hline Ma3 & 22 & 0.82 & High & & & & & & & & \\
\hline Ma4 & 22 & 0.82 & High & & & & & & & & \\
\hline Ma5 & 10 & 0.37 & Low & & & & & & & & \\
\hline Fu1 & 26 & 0.96 & High & & & & & & & & \\
\hline Fu2 & 24 & 0.89 & High & & & & & & & & \\
\hline Fu3 & 25 & 0.93 & High & & & & & & & & \\
\hline Fu4 & 7 & 0.26 & Low & & & & & & & & \\
\hline Fu5 & 20 & 0.74 & Moderate & & & & & & & & \\
\hline
\end{tabular}

Information:

$\sum=$ Total of the score of experts minus 1

$\mathrm{V}=$ Coefficient of Aiken's validity

Based on Table 1, it can be concluded that there are seven items have the low or invalid category. Seven invalid items consist of four items (SS1, SM3, Ma1, Fu4) of the resource factor, one item (Im1) of process factor, and two items (At2 and ED2) of the resources factor. The seven items are considered not to be used to evaluate local curriculum developed by local governments. 


\section{Small-Scale Trial}

Small-scale trial data were analyzed using confirmatory factor analysis (CFA). Before the data is analyzed using CFA, empirical data obtained in the field must be assessed Kaiser-Meyer-Olkin Measure of Sampling Adequacy (KMO) to ensure the samples used deserve analyzed factors. The results of the analysis can be seen in Table 2.

Table 2

The values of KMO and Bartlett's Test

\begin{tabular}{lllll}
\hline Factor & & Resource & Process & Output \\
\hline Kaiser-Meyer-Olkin Measure of Sampling Adequacy. & 0.913 & 0.921 & 0.905 \\
\hline \multirow{3}{*}{ Bartlett's Test of Sphericity } & Approx. Chi-Square & 1342.037 & 807.664 & 588.897 \\
\cline { 2 - 5 } & df & 276.000 & 105.000 & 91.000 \\
\cline { 2 - 5 } & Sig. & 0.000 & 0.000 & 0.000 \\
\hline
\end{tabular}

Based on Table 2 that the value of KMO> 0,5 and Bartlett's Test of Sphericity of 0.00 $(\alpha<0.05)$ for all factors. The value indicates that the sample used is eligible for analysis using factor analysis. Furthermore, it can be seen Summary loading factor of each item analyzed using confirmatory factor analysis. The results of the analysis can be seen from Table 3.

Table 3

Results Analysis of Confirmatory Factor Analysis

\begin{tabular}{lllllllll}
\hline \multicolumn{7}{l}{ Resource } & \multicolumn{3}{c}{ Process } & & Output \\
\hline Item & Loading Factor & Criteria & Item & Loading Factor & Criteria & Item & Loading Factor & Criteria \\
\hline GS1 & 0.48 & Valid & TP1 & 0.58 & Valid & Kn1 & 0.57 & Valid \\
GS2 & 0.58 & Valid & TP2 & 0.62 & Valid & Kn2 & 0.59 & Valid \\
GS3 & 0.73 & Valid & TP3 & 0.62 & Valid & Kn3 & 0.65 & Valid \\
GS4 & 0.68 & Valid & TP4 & 0.56 & Valid & Kn4 & 0.46 & Valid \\
SS2 & 0.43 & Valid & Im2 & 0.56 & Valid & At1 & 0.59 & Valid \\
SS3 & 0.59 & Valid & Im3 & 0.45 & Valid & At3 & 0.40 & Invalid \\
SS4 & 0.45 & Valid & Im4 & 0.67 & Valid & At4 & 0.55 & Valid \\
SS5 & 0.69 & Valid & Im5 & 0.59 & Valid & Sk1 & 0.50 & Valid \\
SM1 & 0.45 & Valid & FA1 & 0.56 & Valid & Sk2 & 0.54 & Valid \\
SM2 & 0.55 & Valid & FA2 & 0.59 & Valid & Sk3 & 0.61 & Valid \\
SM4 & 0.34 & Invalid & FA3 & 0.67 & Valid & Sk4 & 0.49 & Valid \\
Eq1 & 0.59 & Valid & FA4 & 0.63 & Valid & ED1 & 0.52 & Valid \\
Eq2 & 0.45 & Valid & SA1 & 0.56 & Valid & ED3 & 0.64 & Valid \\
Eq3 & 0.64 & Valid & SA2 & 0.57 & Valid & ED4 & 0.57 & \\
Eq4 & 0.43 & Valid & SA3 & 0.42 & Valid & & & \\
Eq5 & 0.44 & Valid & & & & & & \\
Ma1 & 0.44 & Valid & & & & & & \\
Ma2 & 0.56 & Valid & & & & & & \\
Ma3 & 0.60 & Valid & & & & & & \\
Ma4 & 0.48 & valid & & & & & & \\
Fu1 & 0.68 & Valid & & & & & & \\
Fu2 & 0.60 & Valid & & & & & & \\
Fu3 & 0.69 & Valid & & & & & \\
Fu5 & 0.36 & Invalid & & & & & \\
\hline Bas & & & & & &
\end{tabular}

Based on Table 3, there are three invalid items, consisting of two items (SM4 and Fu5) of the resource factorand one item (At3) of the output factor. Invalid items considered to be discarded and not included to evaluate the local curriculum developed by the local government. From the 53 items tested empirically only 50 items that can be used to evaluate the local curriculum developed by local governments with a loading factor of more than 0.4 . 


\section{Reliability}

Reliability of the instrument using Cronbach's Alpha coefficient(Cronbach \& Shavelson, 2004). A good reliability value if the Cronbach's Alpha coefficient is more than 0.7 . The results of the analysis can be seen in Table 4.

Table 4

Reliability Statistics

\begin{tabular}{lll}
\hline Factor & N of Item & Cronbach's Alpha \\
\hline Resources & 24 & 0.907 \\
Process & 15 & 0.878 \\
Output & 14 & 0.848 \\
\hline
\end{tabular}

Based on Table 4, it can be concluded that the developed instrument has a qualified Cronbach's Alpha coefficient so that the instrument can be used to evaluate the local curriculum developed by the local government.

\section{The large-scale trial}

The large-scale trial is performed to see the validity and reliability of the constructs obtained from the factors or components to be evaluated. Constructs or indicators obtained from factors will see validity and reliability. This is done to prove that the constructs found through FGD and literature review are valid and reliable. Validity and Reliability were analyzed with CFA using with the help of Lisrel 8.80 software. The results of the analysis can be seen in Table 5.

Table 5

The Construct Analysis Result of Confirmatory Factor Analysis

\begin{tabular}{llll}
\hline Variable & Indicator /Construct & $\lambda$ & Category \\
\hline \multirow{5}{*}{ Resource } & Government Support & 0.76 & Valid \\
\cline { 2 - 4 } & School Support & 0.72 & Valid \\
\cline { 2 - 4 } & Student Motivation & 0.63 & Valid \\
\cline { 2 - 4 } & Equipment & 0.75 & Valid \\
\cline { 2 - 4 } & Material & 0.79 & Valid \\
\cline { 2 - 4 } & Fund & 0.78 & Valid \\
\hline Prosess & Teaacher Preparation & 0.78 & Valid \\
\cline { 2 - 4 } & Implementation & 0.86 & Valid \\
\cline { 2 - 4 } & Formative Assessment & 0.84 & Valid \\
\cline { 2 - 4 } & Summative Assessment & 0.73 & Valid \\
\hline Output & Knowledge & 0.82 & Valid \\
\cline { 2 - 4 } & Attitude & 0.84 & Valid \\
\cline { 2 - 4 } & Skill & 0.71 & Valid \\
\cline { 2 - 4 } & Entrepreneurial desires & 0.41 & Valid \\
\hline
\end{tabular}

Based on Table 5, the collapse validity value is more than 0.4 . the results of the analysis in Table 5 explain that the constructs of the resource, process, and output factors have acceptable validity values and can be used to evaluate local curriculum developed by local governments. From the analysis results obtained the value of Chi-Square $=69.49$, df $=77$, P-Value $=0.71626$, Root Mean Square Effort of Measurement $($ RMSEA) $=$ 
0.000, Goodness of Fit Index $=0.97$ and Adjusted Goodness of Fit Index (AGFI) $=$ 0.96, Normed Fit Index (NFI) $=0.99$. Based on the value of Goodness of Fit can be concluded that the data obtained the fit with measurements developed. The construct reliability can be seen in Table 6 .

Table 6

Summary of Construct Reliability Analysis

\begin{tabular}{|c|c|c|c|c|}
\hline Variable & Indicator/Construct & $\lambda$ & Error & $\mathrm{CR}$ \\
\hline \multirow[t]{6}{*}{ Resource } & Government Support & 0.76 & 0.43 & \multirow{6}{*}{0.877} \\
\hline & School Support & 0.72 & 0.49 & \\
\hline & Student Motivation & 0.63 & 0.60 & \\
\hline & Equipment & 0.75 & 0.44 & \\
\hline & Material & 0.79 & 0.38 & \\
\hline & Fund & 0.78 & 0.39 & \\
\hline \multirow[t]{4}{*}{ Prosess } & Teaacher Preparation & 0.78 & 0.40 & \multirow{4}{*}{0.878} \\
\hline & Implementation & 0.86 & 0.25 & \\
\hline & Formative Assessment & 0.84 & 0.30 & \\
\hline & Summative Assessment & 0.73 & 0.47 & \\
\hline \multirow[t]{4}{*}{ Output } & Knowledge & 0.82 & 0.34 & \multirow{4}{*}{0.797} \\
\hline & Attitude & 0.84 & 0.30 & \\
\hline & Skill & 0.71 & 0.50 & \\
\hline & Entrepreneurial desires & 0.41 & 0.83 & \\
\hline
\end{tabular}

Based on Table 6 , it can be concluded that the construct reliability results is greater than 0.7 of the resource, process and output factors. The reliability coefficients obtained from Table 6 show that the instrument resources, processes, and outputs can be used to evaluate the local curriculum.

\section{The effectiveness of The Instrument}

Assessment of the effectiveness of the instrument is conducted to see how far the developed instrument is comprehensive, effective in getting information, easy to use, and useful for instrument users to evaluate the local curriculum. Assessment is done 6 vice principals 12 local curriculum teachers who have implemented the instrument. The results of the assessment can be seen in Table 7 .

Tabel 7

The Effectiveness of Developed Instrument

\begin{tabular}{lllllll}
\hline \multicolumn{1}{c}{ Aspects Assessed } & $\mathrm{N}$ & Min & Max & Mean & Std. Deviation & Category \\
\hline The instrument developed is comprehensive & 18 & 2.00 & 4.00 & 3.22 & .73 & Good \\
The instrument developed is accurate & 18 & 2.00 & 4.00 & 3.56 & .70 & Very Good \\
The instrumentdeveloped is easy to use & 18 & 3.00 & 4.00 & 3.50 & .51 & Very Good \\
The instrumentdeveloped is useful & 18 & 2.00 & 4.00 & 3.61 & .61 & Very Good \\
\hline
\end{tabular}

From the assessment of the vice principal and the local curriculum teacher, the average score was obtained from 3.22 to 3.61. Principals and teachers assess all aspects of the effectiveness of the instruments are in very good and good category. Assessment of vice principals and teachers indicates that the instruments developed are effective in 
obtaining information about the local curriculum. In other words, the instruments used are effective in obtaining accurate data on local curriculum implementation.

\section{DISCUSSION AND CONCLUSION}

To evaluate the local curriculum developed by the local government requires a valid and reliable instrument since valid instruments can provide accurate information on the weaknesses and deficiencies of the developed curriculum by local government. Instruments must be valid and reliable in content and construct since the validiy and reliablility are important parts of the development of the instrument (Wynd, Schmidt, \& Schaefer, 2003). Validity and reliability are used to ensure the measurement runs maximally and the implementation of educational programs goes well (Wright \& Craig, 2011). Reliability and validity are the entities required in instrumental development(Burton \& Mazerolle, 2011). Researchers who develop instruments in the field of education, psychology and other social need to pay attention to the importance of the concept of validity and reliability so that information needed to support research can be obtained accurately.

The instrument developed to evaluate local content curriculum is effective. The instrument is comprehensive, easy to use, accurate in obtaining information about the weaknesses and strengths of the local curriculum and is very beneficial to governments and schools.Effective instruments will make it easier for users to access information that hinders a program's success(Tooth, Nielsen, \& Armstrong, 2013). Effective instruments can describe the components that need to be improved so as to contribute strongly to improve a developed program. A valid, reliable and proven effective instruments will show the results of measurement, so stakeholders can improve the shortcomings of educational programs (Widodo \& Sudarsono, 2016).

The instruments developed to evaluate the local curriculum consist of, resource instruments, process instruments, and output instruments. The result of validation by the expert shows that there are 7 items invalid items and can not be used to evaluate the local curriculum. The results of the validity and reliability analysis on small-scale trials show that there are 3 invalid items, consisting of 2 of the resource factors and 1 of the output factors. The results of the analysis of large-scale trials show that all constructs derived from the FGD and the study of literature have a value of valid and reliable instrument that can be used to evaluate the local curriculum. Of the 60 items developed, only 50 items could be used to evaluate the local curriculum, consisting of 22 items from the resource factor, 15 items from the process factor and 13 items from the output factor. The developed measurements meet the statistical Goodness of Fit criteria. The instruments have been developed effectively to evaluate local curriculum developed by local governments.

\section{REFERENCES}

Aiken, L. R. (1980). Content Validity and Reliability of Single Items or Questionnaires. Educational and Psychological Measurement, 40(V), 955-959.

Akınoğlu, O. (2017). Pre- Service Teachers' Meta phorical Perceptions Regarding the 
Concept of Curriculum. International Journal of Instruction, 10(2), 263-278.

Bayraktar, E., Tatoglu, E., \& Zaim, S. (2008). An instrument for measuring the critical factors of TQM in Turkish higher education. Total Quality Management and Business Excellence, 19(6), 551-574. https://doi.org/10.1080/14783360802023921

Borg, W R \& Gall, M. D. (1983). Educational Research Forth Edition. New York: Longman.

Briggs, C. L. (2007). Curriculum Collaboration: A Key to Continuous Program Renewal. The Journal of Higher Education, 78(6), 676-711. https://doi.org/10.1353/jhe.2007.0036

Brundrett, M., \& Duncan, D. (2011). Leading curriculum innovation in primary schools. Management in Education, 25(3), 119-124. https://doi.org/10.1177/0892020610387957

Burton, L. J., \& Mazerolle, S. M. (2011). Survey Instrument Validity Part I: Principles of Survey Instrument Development and Validation in Athletic Training Education Research. Journal of Athletic Training Education, 6(1), 27-35.

Cashmore, M., Bond, A., \& Sadler, B. (2009). Introduction: The effectiveness of impact assessment instruments. Impact Assessment and Project Appraisal, 27(2), 91-93. https://doi.org/10.3152/146155109X454285

Chan, R. K. H., \& Wang, Y. (2009). Controlled decentralization: minban education reform in China. Journal of Comparative Social Welfare, 25(1), 27-36. https://doi.org/10.1080/17486830802513983

Chapman, D., Barcikowski, E., Sowah, M., Gyamera, E., \& Woode, G. (2002). Do communities know best? Testing a premise of educational decentralization: Community members' perceptions of their local schools in Ghana. International Journal of Educational Development, 22(2), 181-189. https://doi.org/10.1016/S07380593(01)00026-8

Cronbach, L. J., \& Shavelson, R. J. (2004). My Current Thoughts on Coefficient Alpha and Successor Procedures. Educational and Psychological Measurement, 64(3), 391418. https://doi.org/10.1177/0013164404266386

Curtis, C., \& Norgate, R. (2007). An Evaluation of the Promoting Alternative Thinking Strategies Curriculum at Key Stage 1. Educational Psychology in Practice, 23(1), 3344. https://doi.org/10.1080/02667360601154717

Depdiknas. (2006). Peraturan Menteri Pendidikan Nasional Republik Indonesia Nomor 22 Tahun 2006. Lampiran Tentang Standar Isi, 1-48

Doherty, C., \& Shield, P. (2012). Teachers' Work in Curricular Markets: Conditions of Design and Relations Between the International Baccalaureate Diploma and the Local Curriculum. Curriculum Inquiry, 42(3), 414-441. https://doi.org/10.1111/j.1467873X.2012.00596.X

Eğmir, E., Erdem, C., \& Koçyiğit, M. (2017). Trends in Educational Research: A Content Analysis of the Studies Published in International Journal of Instruction. International Journal of Instruction, 10(3), 277-294. 


\section{https://doi.org/10.12973/iji.2017.10318a}

Emin, M. (2013). The Role of Education as a Tool in Transmitting Cultural Stereotypes Words. International Journal of Humanities and Social Science, 3(15), 57-65. Retrieved from www.ijhssnet.com

Festus, A., \& Kurumeh, M. (2015). Curriculum planning and development in mathematics from formative stages. Journal of Education and Practice, 6(2), 62-66.

Fink, C.R., \& Crunkilton, J. . (1999). Curriculum development in vocational and technical education. Planning, content, and implementation. Boston: Allyn and Bacon Inc.

Gavareshki, M. N., Haddadian, F., \& HassanzadehKalleh, M. (2012). The Role of Education, Educational Processes, and Education Culture on the Development of Virtual Learning in Iran. Procedia - Social and Behavioral Sciences, 46(Bruner 1996), 5379 5381. https://doi.org/10.1016/j.sbspro.2012.06.442

Gilbert, R. (2004). A framework for evaluating the doctoral curriculum. Assessment and

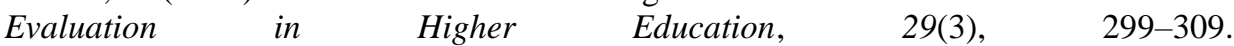
https://doi.org/10.1080/0260293042000188258

Haghparast, N., Sedghizadeh, P. P., Shuler, C. F., Ferati, D., \& Christersson, C. (2007). Evaluation of student and faculty perceptions of the PBL curriculum at two dental schools from a student perspective: a cross-sectional survey. European Journal of Dental Education, 11(1), 14-22. https://doi.org/10.1111/j.1600-0579.2007.00423.x

Hall, P. (2005). Interprofessional teamwork: Professional cultures as barriers. Journal of Interprofessional Care, 19(SUPPL. 1) https://doi.org/10.1080/13561820500081745

Harris, L., Driscoll, P., Lewis, M., Matthews, L., Russell, C., \& Cumming, S. (2010). Implementing curriculum evaluation: Case study of a generic undergraduate degree in health sciences. Assessment and Evaluation in Higher Education, 35(4), 477-490. https://doi.org/10.1080/02602930902862883

Heimlich, J. E. (2010). Environmental education evaluation: Reinterpreting education as a strategy for meeting mission. Evaluation and Program Planning, 33(2), 180-185. https://doi.org/10.1016/j.evalprogplan.2009.07.009

Howell, K.W.,\& Nolet, V. (2000). Curriculum based evaluation: teaching and decision making. Belmont: Wadswortth Thomson Learning.

Jacob, B. A., \& Lefgren, L. (2008). Can Principals Identify Effective Teachers? Evidence on Subjective Performance Evaluation in Education. Journal of Labor Economics, 26(1), 101-136. https://doi.org/10.1086/522974

Johansson, G. (2009). Parental involvement in the development of a culture-based school curriculum. Intercultural Education, 20(4), 311-319. https://doi.org/10.1080/14675980903351946

Law, E. H. (2009). School-based curriculum innovations : A case study in mainland China, l(1), 156-166. 
Lie, D. A., John, B., Crandall, S., Degannes, C. N., Henderson, P., Kodjo, C., ... Degannes, C. N. (2009). Revising the Tool for Assessing Cultural Competence Training ( TACCT ) for curriculum evaluation: Findings derived from seven US schools and expert consensus. Medical Education Online, 13(11), 1-15. https://doi.org/10.3402/meo.v13i.4480

Mcgaw, B. (2013). Keywords : Curriculum , Australian Curriculum , curriculum development, national, 55(3), 43-52.

Mølstad, C. E. (2015). State-based curriculum-making: Approaches to local curriculum work in Norway and Finland. Journal of Curriculum Studies, 47(4), 441-461. https://doi.org/10.1080/00220272.2015.1039067

Morrison-Saunders, A., \& Arts, J. (2004). Assessing Impact.Handbook of EIA and SEA follow-up. London: Earthscan

Papadopoulou, V., \& Yirci, R. (2013). Rethinking Decentralization in Education in terms of Administrative Problems. Educational Process: International Journal , 2(1-2), $7-18$.

Prastiwi, Y. (2013). Transmitting Local Cultural Knowledge through English as Foreign Language (EFL) Learning as a Means of Fostering "Unity in Diversity." Academic $\begin{array}{llll}\text { Journal of Interdisciplinary } & \text { Studies, } & 2(3), & 507-514 .\end{array}$ https://doi.org/10.5901/ajis.2013.v2n3p507

Qi, T. (2011). Moving Toward Decentralization? Changing Education Governance in China After 1985. The Impact and Transformation of Education Policy in China (Vol. 15). Emerald Group Publishing Ltd. https://doi.org/doi:10.1108/S14793679(2011)0000015005

Sahasewiyon, K. (2004). Working Locally as a True Professional: case studies in the development of local curriculum through action research in the context of Thai schools. Educational Action Research, 12(4), 493-514.

Salim Saif Al-Jardani, K. (2012). English Language Curriculum Evaluation in Oman. International Journal of English Linguistics, 2(5), 40-44. https://doi.org/10.5539/ijel.v2n5p40

Shih, P., Velan, G. M., \& Shulruf, B. (2017). Shared values and socio-cultural norms: Elearning technologies from a social practice perspective. Issues in Educational Research, 27(3), 550-566.

Squires, D. A. (2013). The Balanced Curriculum Model: Description and Results. SAGE Open, 3(1), 1-10. https://doi.org/10.1177/2158244013478012

Środa-Murawska, S., Biegańska, J., \& Dąbrowski, L. (2017). Perception of the role of culture in the development of small cities by local governments in the context of strategic documents - a case study of Poland. Bulletin of Geography. Socio-Economic Series, 38(38), 119-129. https://doi.org/10.1515/bog-2017-0038

Strouse, S. M., \& Nickerson, C. J. (2016). Professional culture brokers: Nursing faculty perceptions of nursing culture and their role in student formation. Nurse Education in Practice, 18, 10-15. https://doi.org/10.1016/j.nepr.2016.02.008 
Sultan, Rofiuddin, A., Nurhadi, \& Priyatni, E. T. (2017). The development of a critical reading learning model to promote university students' critical awareness. New Educational Review, 48(2004), 76-86. https://doi.org/10.15804/tner.2017.48.2.06

Syomwene, A., Kitainge, K., \& Mwaka, M. (2013). Psychological Influences in the Curriculum Decision Making Process. Journal of Education and Practice, 4(8), 173181. https://doi.org/ISSN 2222-1735

Temli Durmuş, Y. (2016). Effective Learning Environment Characteristics as a requirement of Constructivist Curricula: Teachers' Needs and School Principals' Views. International Journal of Instruction, 9(2), 183-198. https://doi.org/10.12973/iji.2016.9213a

Tooth, J. A., Nielsen, S., \& Armstrong, H. (2013). Coaching effectiveness survey instruments: Taking stock of measuring the immeasurable. Coaching, 6(2), 137-151. https://doi.org/10.1080/17521882.2013.802365

Tubadji, A. (2012). Culture-based development: empirical evidence for Germany. International Journal of Social Economics, 39(9), 690-703. https://doi.org/10.1108/03068291211245718

Umami, I. (2018). Moderating Influence of Curriculum, Pedagogy, and Assessment Practices on Learning Outcomes in Indonesian Secondary Education Ida Umami 1, 9(1), 60-75.

Ungar, W. J., \& Santos, M. T. (2003). The pediatric quality appraisal questionnaire: An instrument for evaluation of the pediatric health economics literature. Value in Health, 6(5), 584-594. https://doi.org/10.1046/j.1524-4733.2003.65253.x

Widodo, E., \& Sudarsono, F. (2016). Developing an observation instrument for assessing the effectiveness of english teaching at vocational secondary schools. Research and Evaluation in Education, 2(2), 135-154.

Wright, P. M., \& Craig, M. W. (2011). Tool for assessing responsibility-based education (TARE): Instrument development, content validity, and inter-rater reliability. Measurement in Physical Education and Exercise Science, 15(3), 204-219. https://doi.org/10.1080/1091367X.2011.590084

Wynd, C. A., Schmidt, B., \& Schaefer, M. A. (2003). Two quantitative approaches for estimating content validity. Western Journal of Nursing Research, 25(5), 508-518. https://doi.org/10.1177/0193945903252998

Zedda, M., Bernardelli, S., \& Maran, D. A. (2017). Students' Satisfaction with the Group Work Method and its Performance Evaluation: A survey in an Italian University. International Journal of Instruction, 10(3), 1-14. https://doi.org/10.12973/iji.2017.1031a 